\title{
KÉMIAI HARMADLAGOS KŐOLAJKITERMELÉSRE ALKALMAS POLIMER-TENZID OLDATOK FOLYÁSI TULAJDONSÁGAINAK HŐMÉRSÉKLETFÜGGÉSE
}

\section{TEMPERATURE DEPENDENCE OF FLOW PROPERTIES OF POLYMER-SURFACTANT SOLUTIONS FOR CHEMICAL ENHANCED OIL RECOVERY}

\author{
Kothencz Réka ${ }^{1}$, Nagy Roland ${ }^{2}$, Bartha László ${ }^{3}$, Vágó Árpád ${ }^{4}$ \\ ${ }^{I}$ Pannon Egyetem, Mérnöki kar, Vegyipari Müveleti Intézeti Tanszék, Magyarország, \\ 8200 Veszprém, Egyetem utca 10.; Telefon: +3688/624-305, kothenczr@almos.uni- \\ pannon.hu \\ ${ }^{2}$ Pannon Egyetem, Mérnöki kar, MOL Ásványolaj- és Széntechnológia Intézeti Tan- \\ szék, Magyarország, 8200 Veszprém, Egyetem utca 10.; Telefon: +3688/ 624-412, \\ nroland@almos.uni-pannon.hu \\ ${ }^{3}$ Pannon Egyetem, Mérnöki kar, Vegyipari Müveleti Intézeti Tanszék, Magyarország, \\ 8200 Veszprém, Egyetem utca 10.; Telefon: +3688/624-305, bartha@almos.uni- \\ pannon.hu
}

${ }^{4}$ MOL NyRt, Csoportszintü Kutatás és Üzletfejlesztés, 1117 Budapest, Októberhuszonharmadika utca18., avago@mol.hu

\begin{abstract}
High-performance emulsifiers and surfactants are used in enhanced oil recovery (EOR). During the polymer-surfactant flooding flow modifier polymer and surfactant are mixed, which reduce the surface tension. It allows to control the mobility and to increase the efficiency of the production. The rheological behaviour of the polymeric, aqueous solutions of surfactants was analysed and their effect on the temperature was studied. The movability of the injected fluid can be predicted by the rheological results which is a significant property for the oil production. Furthermore, informations related to the structure of the polymer-surfactant associates can be obtained by the rheological caracteristics.
\end{abstract}

Keywords: EOR, rheology, polymer, surfactants

\section{Összefoglalás}

A harmadlagos kőolaj-kitermelés (EOR) feltétele a nagy hatékonyságú felületaktív anyagok, tenzidek alkalmazása. A polimer-tenzides elárasztás során folyásmódosító polimert és felületi feszültséget csökkentő tenzideket kevernek össze és oldanak fel rétegvízben, amely segítségével szabályozzák a mobilitást és növelik a kitermelési hatásfokot. Célunk volt a növényolaj alapú tenzidek polimeres, rétegvizes oldatainak reológiai vizsgálata és hőmérsékletfüggésének tanulmányozása. A reológiai vizsgálatok eredményéből következtetni tudunk a besajtolandó fluidum mozgathatóságára, ami a kőolaj-kitermelés szempontjából fontos tulajdonság. Továbbá a reológiai tulajdonságok vizsgálatakor a kialakult polimer-tenzid asszociátum szerkezetével kapcsolatos információt is kaphatunk.

Kulcsszavak: EOR, reológia, polimer, tenzid. 


\section{Bevezetés}

A kőolajtározók kimerülésének következtében folyamatosan csökken az elsődleges és másodlagos kitermelő eljárások alkalmazásával nyert kőolaj mennyisége, mert a tárolók elvizesednek és lecsökken a rétegnyomásuk. A tározókban viszont még igen jelentős olajmennyiség található, amelynek felszínre hozatalát a harmadlagos kitermelési eljárások teszik lehetővé. A harmadlagos kőolaj-kitermelés egyik típusának során felhasznált tenzid a rétegvízzel és a kőolajjal emulziót képez, eközben csökkenti a határfelületi feszültséget és így az olajrészecskéket a pórusokon keresztül kimossa, így a képződött emulzió a termelőkúton távozik. Erre a célra a növényi olaj alapú tenzideket a köolajiparban is egyre szélesebb körben alkalmazzák. A környezetvédelmi szempontból is kedvezö növényolaj alapú nemionos tenzidek nemcsak az élelmiszeriparban és a kozmetikaiparban, hanem a kőolajiparban is meghatározó szerepet töltenek be [1,2].

Célunk a folyásmódosító polimert és felületi feszültség csökkentö tenzidkompozíciókat tartalmazó rétegvizes oldatok reológiai tulajdonságainak vizsgálata volt, ami azért fontos, mert abból következtetni lehet a besajtolandó fluidum szerkezetére, mozgathatóságára, illetve besajtolhatóságára. Mivel a viszkozitás a hőmérséklet függvényében változik, ezért a vizsgálatok a gyakorlati felhasználáshoz nyújthatnak hasznos információt.

\section{Felhasznált anyagok, alkalma- zott módszerek}

Az egyes mérések elvégzéséhez különböző típusú anionos és nemionos tenzidekből elő́llított tenzidkompozíciókat használtunk fel, amelyeket rétegvízben feloldott folyásmódosító polimerrel kevertünk össze. Az anionos tenzidet 60 tömeg\%-ban, míg a nemionos tenzidet 40 tömeg\%-ban tartalmazta a vizsgált tenzidkompozíció.

Munkánk során a reológiai mérésekhez az Anton Paar dynamic shear rheometert koncentrikus hengercellával alkalmaztuk. A méréseket $25,30,40,50,60,70$ és $80^{\circ} \mathrm{C}$-on végeztük 10 és 1000 1/s nyírási sebesség gradiens között.

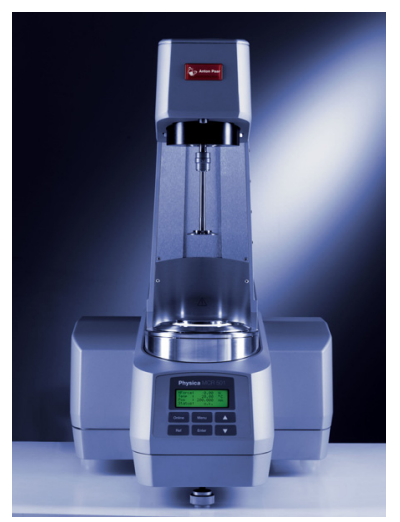

1. ábra. Anton Paar Dynamic Shear Reométer

\section{Mérési eredmények}

A besajtolandó folyadékok reológiai tulajdonságait a dinamikai viszkozitásnak a nyírási sebesség függvényében történő mérésével végeztük. A kis és a nagy nyírási sebesség értékekhez tartozó dinamikai viszkozitás egyaránt fontos, hiszen a felhasználás során a besajtolandó fluidum mozgása mindkét nyírási sebességtartományban megtörténik. Vizsgálatainkat a folyásmódosító polimer rétegvizes oldatának dinamikai viszkozitás változásának mérésével kezdtük, amely a 2. ábrán látható. Emellett a dinamikai viszkozitás változásának hőmérsékletfüggését is vizsgáltuk. A felhasználás során ugyanis széles hőmérsékletgradiens alakul ki, ezért alkalmazástechnikailag meghatározó a hőmérsékletfüggés megismerése. A felszínröl a kőolajtároló rétegbe történő besajtolás során a különböző tároló rétegekben akár $60^{\circ} \mathrm{C}$-os hömérsékletkülönbség is lehetséges magyarországi viszonylatban. 


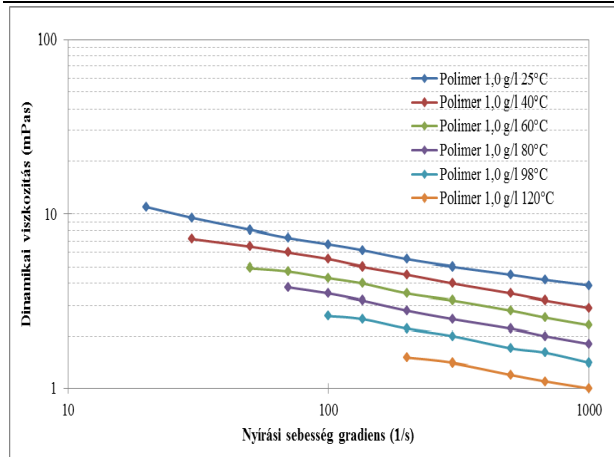

2. ábra. Folyásmódositó polimer oldat dinamikai viszkozitásának hömérsékletfüggése

Megállapítottuk, hogy $20-90^{\circ} \mathrm{C}$ között a polimeroldat 1 és 10,5 mPas közötti viszkozitás értéket vesz fel, mely a fluidum mozgathatóságát lehetővé teszi a tárolórétegben. A görbék alapján látható, hogy a polimeroldat nem newtoni viselkedésü.

Megvizsgáltuk a tenzidkompozíciók rétegvizes oldatának dinamikai viszkozitásváltozását a nyírási sebesség gradiens függvényében, különböző hőmérsékleteken. A mérési eredményeket a 3. ábra illusztrálja.

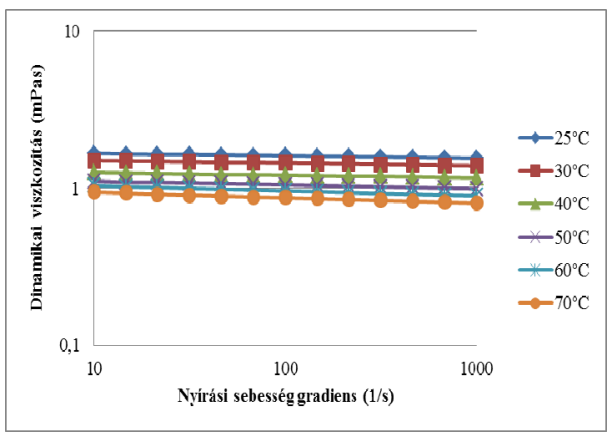

3. ábra. A tenzidkompozíció vizes oldatának dinamikai viszkozitásának hömérsékletfüggése

A $\quad 25-70^{\circ} \mathrm{C}$-ig végzett reológiai vizsgálatok alapján megállapítottuk, hogy a vizsgált tenzidkompozícióból készült oldat közel newtoni viselkedésünek mondható. Így a tenzidoldatok dinamikai viszkozitása a besajtolás szempontjából megfelelö, a vizsgált nyírási sebesség tartományban új, dinamikai viszkozitás változással járó szerkezet kialakulását nem tapasztaltunk [3].

Vizsgálatunkat a folyásmódosító polimert is tartalmazó tenzidkompozíciók rétegvizes oldatának tanulányozásával folytattuk. A kőolajkitermelés szempontjából a legfontosabb ezen oldatok vizsgálata. A mérési eredményeket a 4. ábra szemlélteti.

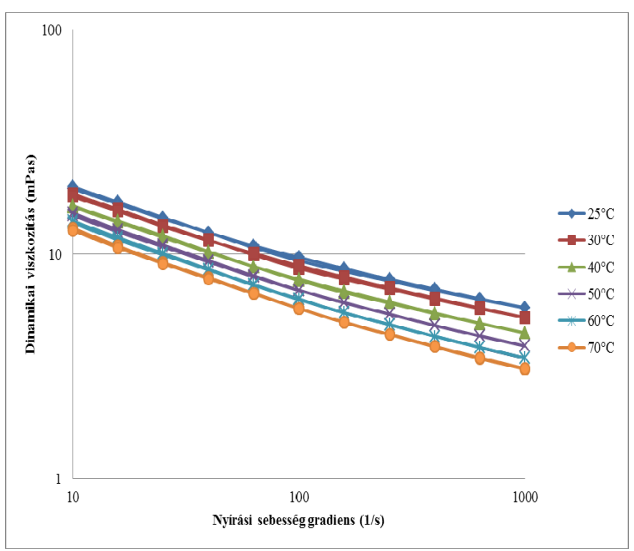

4. ábra. A tenzid polimeres rétegvizes oldatának dinamikai viszkozitása különbözö hömérsékleteken

Megállapítottuk, hogy polimer-tenzid oldatok dinamikai viszkozitása nagyságrenddel nagyobb, mint önállóan a tenzidoldat dinamikai viszkozitása, valamint adott hőmérsékleten a polimeroldat és a tenzidoldat viszkozitásának összegénél is nagyobb az adott hömérsékleten mért polimeres tenzidoldat dinamikai viszkozitása. Ezen eredmények alapján a polimer és a tenzid alkotta asszociátum, azaz új szerkezet kialakulását feltételezzük. A folyásmódosító polimert és a polimeres tenzidoldatok viszkozitásgörbéinek meredekségét vizsgálva azt találtuk, hogy a polimeres tenzidoldatok meredeksége jelentősen csökken, mintegy 25-öd részére. A szakirodalmi közlemények meglehetösen hiányosak e jelenség részletes vizsgálatáról, 
mégis a polimer-tenzid közötti szinergiát a hatékony és eredményes kőolajkitermelés alapjaként említik [4]. Ezért részletesebb, reológiához kapcsolódó kiegészitő vizsgálatok elvégzését tervezzük a jövőben.

\section{Következtetések}

A kőolajtárolók kimerülésének következtében a kihozatalnövelö eljárások egyre inkább előtérbe kerülnek. Ezért folyásmódosító polimert és tenzidkompozíciót is tartalmazó rétegvizes oldatok reológiai tulajdonságainak vizsgálatát elvégeztük, amely alapján megállapítottuk, hogy önállóan a polimer és a tenzidkompozíció vizes oldata relatíve kis dinamikai viszkozitással rendelkeznek. Az alkalmazott polimer és tenzidkompozíció együttesen rétegvízben oldva asszociátumot alakít ki, mely a dinamikai viszkozitás viszonylagosan nagy növekedéséből valószínüsítettünk. Ez a növekedés az egyes komponensek viszkozitásának additív összegénél lényegesen nagyobb volt. A polimert tartalmazó tenzidoldatok meredeksége jelentős mértékben csökkent, mely szintén a polimer-tenzid asszociátum kialakulását jelzi.

Összességében megállapítottuk, hogy a felhasználandó tenzidkompozíció és a folyásmódosító polimer reológiai szempont- ból elönyösen alkalmazható, azonban részletesebb vizsgálatok szükséges a folyamatok teljes megismeréséhez.

\section{Szakirodalmi hivatkozások}

[1] Laurier L. Schramm: Emulsions, Fundamentals and applications in the petroleum industry, American Chemical Society, Washington DC, 1992.

[2] D. J. Shaw: Bevezetés a kolloid- és felületi kémiába, Müszaki Könyvkiadó, Budapest, 1986

[3] H. A. Barnes, J. F. Hutton, K. Walters: $A n$ Intorduction to Rheology, Elsevier Science Publisher B.V., 1993.

[4] J. Hou, Z. Liu, S. Zhang, X. Jue, J. Yang: The role of viscoelasticity of alkali/surfactant/polymer solutions in enhanced oil recovery, Journal of Petroleum Science and Engineering, 47, 2005, 219-235.

\section{Köszönetnyílvánítás}

A szerzők köszönetet mondanak a cikk elkészítéséért:

MOL Nyrt., Csoportszintü Kutatás \& Üzletfejlesztés támogatásáért. 